
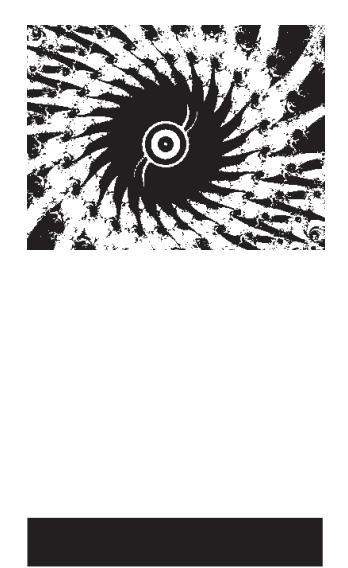

Rad je izrađen okviru projekta Prilagodba pojedinca i zajednice u vrijeme društvene tranzicije broi projekta 130-1301422-1418, koii financira Ministarstvo znanosti, obrazovanja i sporta Republike Hrvatske.

\title{
ŠTO ODREĐUJE MEĐUETNIČKE STAVOVE ADOLESCENATA U PODIJELJENOJ ZAJEDNICI?
}

Dinka ČORKALO BIRUŠKI, Dean AJDUKOVIĆ Filozofski fakultet, Zagreb

UDK: 316.644-053.6(497.5Vukovar):323.15

Izvorni znanstveni rad

Primljeno: 10. 7. 2012.

Škola je jedan od najvažnijih socijalizacijskih agenasa. Osim znanja, škola prenosi i društvene norme i nacionalne vrednote, čuva etnički identitet i njeguje društveno poželina ponašanja. Identitetna funkcija škole posebno je istaknuta u obrazovanju manjina, pa ovaj rad ispituje mogućnost predikcije stavova prema školskoj i socijalnoj integraciij djece u Vukovaru, koja se školuju u specifičnom kontekstu odijeljenih razreda u kojima se nastava odvija na hrvatskom te na srpskom jeziku i pismu. Ovaj je sustav uspostavlien Erdutskim sporazumom 1995. i traje i danas. Cili je ovog rada ispitati mogućnost predikcije stavova prema školskoj i izvanškolskoj integraciii djece na temelju sociodemografskih $\mathrm{i}$ identitetnih varijabli, stava prema vrijednosti obrazovanja te međuetničkih stavova i ponašanja. Hijerarhijske regresij|ske analize stava prema školskoj i izvanškolskoj integraciii na podacima hrvatske i srpske djece od 12 do 16 godina, prikuplienima 2001. godine $(N=718)$ i 2007. godine $(N=703)$, pokazale su da su identitet, te međuetnički stavovi i ponašanja, vrlo dobar prediktor integracijskih stavova, i to bolji kod većine i nešto bolii prema školskoj integraciij. S vremenom međuetnički stavovi postaju sve bolii prediktor integraciiskih stavova, upućujući na sve snažniju unutaretničku homogenizaciju djece. Rezultati su interpretirani pod vidom odnosa većine i manjine u multietničkim zajednicama te je istaknuta uloga škola u integracijskim procesima.

Ključne riječi: međuetnički stavovi i ponašanja, manjinsko obrazovanje, etnički identitet, odnosi manjine i većine 
Odnos međugrupnih stavova i ponašanja središnje je pitanje opće teorije međugrupnih odnosa u društvenim znanostima, a njihov je značaj posebno istaknut $u$ multietničkim sredinama. Ovaj rad smješta prediktivni model specifičnoga seta stavova - stavova prema socijalnoj integraciji i stavova prema školskoj integraciji - u kontekst i opće teorije kontakta (Allport, 1954.; Pettigrew i Tropp, 2011.) i teorije socijalnog identiteta (Tajfel i Turner, 1986.). Središnji pojam potonje teorije definiran je kao dio pojma o sebi koji proizlazi iz pripadnosti pojedinca socijalnim grupama (Tajfel i Turner, 1986.). Pozitivno vrednovanje vlastite grupe i njezin povoljni socijalni status u kontekstu u kojem uspoređujemo svoju i vanjske grupe izvor su pozitivnoga socijalnog identiteta. Suprotno, negativan društveni status grupe kojoj pripadamo izvorom su negativnoga socijalnog identiteta. Pozicija vlastite grupe ima posebnu važnost $u$ uvjetima jasnih manjinsko-većinskih odnosa (Tajfel, 1978.), a u kontekstu identitetno podijeljene zajednice postaje i bitna (Čorkalo Biruški i Ajduković, 2012.a; Gallagher, 2004.; Verkuyten, 2005.a; Verkuyten i Reijerse, 2008.; Wagner i sur., 2008.).

Sama kategorijalna pripadnost, dakle puka svrstanost $\mathrm{u}$ grupu, čini njezine članove pozitivno pristranima prema njoj. Ova unutargrupna pristranost očituje se u "sistematskoj tendenciji" povoljnijega vrednovanja članova vlastite grupe nego vanjske grupe (Hewstone i sur., 2002.). Posljedica je čiste kategorizacije, pa autori teorije socijalnog identiteta tvrde da je riječ o "sveprisutnom obilježju međugrupnih odnosa" (Tajfel i Turner, 1986., 13). Premda za njezino javljanje nije nužan sukob među grupama, nego njihovo puko (odijeljeno) postojanje, unutargrupna pristranost u uvjetima sukoba i/ili percipirane prijetnje prelazi razine favoritizma te može poprimiti oblik otvorenih predrasuda, dehumaniziranja druge grupe ili otvorene diskriminacije (npr. Shamir i Sagiv-Schifter, 2006.). Suprotno, u uvjetima u kojima se mogu nadrasti pojedinačne grupne pripadnosti, npr. uključivanjem u zajedničku kategoriju, unutargrupna se pristranost smanjuje (npr. Gaertner i Dovidio, 2009.). Ovaj je fenomen i razvojno prisutan - pojavljuje se već u dobi od 5 ili 6 godina i kulturalno je univerzalan (Barrett, 2007.). Dok u djetinjstvu kognitivno sazrijevanje utječe na manifestacije ovoga, ali i drugih, oblika predrasuda, $u$ adolescenciji se više ne bilježe odvojivi razvojni trendovi, što upućuje na to da s dobi socijalni kontekst, a ne više kognitivno sazrijevanje, ima značajniji utjecaj (Raabe i Beelmann, 2011.; Oppenheimer i Barret, 2011.). U ovom je radu unutargrupna pristranost tretirana kao pokazatelj unutargrupne zatvorenosti te, zajedno s mjerom nacionalnog identiteta, kao najsalijent- 
DRUŠ. ISTRAŽ. ZAGREB GOD. 21 (2012), BR. $4(118)$

STR. $901-921$

ČORKALO BIRUŠKI, D., AJDUKOVIĆ, D.: niji aspekt socijalnog identiteta u našim istraživačkim okolnostima, kao identitetna varijabla.

Da je kontakt među grupama temelj za uspostavu pozitivnih odnosa među njima, gotovo da je socijalnopsihološki aksiom. Od Allportove eksplikacije optimalnih uvjeta koji su nužni da bi kontakt bio učinkovit (Allport, 1954.), pa do najsuvremenijih istraživanja (Pettigrew i Tropp, 2011.), nalazi pokazuju nužnost kontakta u borbi protiv predrasuda. Veza kontakta i predrasuda snažnija je kod većine nego kod manjine (Tropp i Pettigrew, 2005.), a istraživanja pokazuju i da postoji uzročno-posljedični slijed utjecaja kontakta na predrasude, ali ne i obrnuto (Brown i sur., 2007.), premda ima i drugačijih, također longitudinalnih, nalaza (Binder i sur., 2009.). U skladu s tim, istraživanja pokazuju da kreiranje uvjeta za optimalni kontakt može posebno povoljno utjecati na stvaranje pozitivnih međugrupnih stavova kod većinske, nešto manje kod manjinske djece (Wright i Tropp, 2005.; Tropp i Prenovost, 2008.; Feddes i sur., 2009.). To vrijedi i za školske uvjete, koji se općenito pojavljuju kao okolina u kojoj je najlakše i najprirodnije proučavati kontakte djece koji pripadaju različitim rasnim i etničkim grupama (Schofield i Eurich-Fulcer, 2003.; Tropp i Prenovost, 2008.; Pettigrew i Tropp, 2011.). Tako se pokazalo da su kontakti u školi povezani s pozitivnim međugrupnim stavovima, posebno onda kada su u školskim okolnostima ostvareni uvjeti za optimalan kontakt (Tropp i Prenovost, 2008.), premda ti optimalni uvjeti mogu biti ponešto različiti za većinu i za manjinu (Tropp i Pettigrew, 2005.). Ovaj rad uzima u obzir i mjeru kontakta kao vjerojatan i teorijski utemeljen prediktor međugrupnih stavova.

Odnos prema vanjskoj grupi, posebno u kontekstu većinsko-manjinskih odnosa, određen je i klasterima stavova koji odražavaju odnos prema realitetu međuetničkih sredina. To je stav tolerancije prema različitostima ili stav prema multikulturnosti te stav prema asimilaciji (nacionalnih) manjina. Istraživanja u multikulturnim kontekstima pokazuju da su većinske grupe značajno manje sklone multikulturnosti od manjinskih (Verkuyten, 2005.b), dok obrnuti odnos vrijedi za asimilacionizam - dok ga manjine nastoje izbjeći i protive mu se, za većinu je on povoljno rješenje upravljanja međuetničkim odnosima (Verkuyten, 2008.). Ovi nalazi potvrđeni su i u našem kontekstu (Čorkalo Biruški i Ajduković, 2008.a, 2012.a); štoviše, stav prema multikulturnosti i asimilaciji manjina pokazuje se stavom u kojem se većina i manjina najviše razlikuju. Stoga je u ovom radu pretpostavljeno da će i stav prema multikulturnosti i stav prema asimilaciji biti značajni prediktori stavova prema školskoj i socijalnoj integraciji. 


\section{Socijalni kontekst školovanja djece u Vukovaru}

Stekavši status manjine osamostaljenjem Republike Hrvatske, Srbi u Hrvatskoj suočili su se s izazovom uređenja manjinskih prava i njihova pregovaranja s hrvatskom većinom. Nakon četiri godine rata Erdutski je sporazum bio prvi dokument koji je dao okvir za uređenje položaja srpske manjine $u$ Hrvatskoj.

Premda se ni jedna od 14 točaka sporazuma ne odnosi izravno na pitanje obrazovanja srpske manjine, sporazum je iskorišten kao okvir za uređenje i ovoga pitanja. Srpska je manjina, pozivajući se na ustavno pravo školovanja na materinskom jeziku i pismu ${ }^{1}$ u Podunavlju, iskoristila pravo formiranja razrednih odjeljenja $\mathrm{u}$ vertikali obrazovnoga sustava (uključujući i vrtiće), u kojima se nastava odvija isključivo na srpskom jeziku i ćiriličnom pismu (tzv. model A manjinskoga obrazovanja, vidi opširnije u Čorkalo Biruški i Ajduković, 2008.a te Mesic i Baranovic, 2005.). Takva je jezična podjela obrazovanja zaživjela i u Vukovaru, gdje ovaj sustav obrazovanja bazično znači podjelu djece po etničkom ključu (o tome detaljnije vidjeti u Čorkalo Biruški i Ajduković, 2012.b).

Naša istraživanja pokazuju da se podrška A modelu smanjuje tijekom vremena i kod djece i kod odraslih u obje etničke grupe te da je podrška veća kod djece (Čorkalo Biruški i Ajduković, 2012.b). Međutim, stručna rasprava o najprikladnijem modelu školovanja srpske manjine i posljedicama za socijalnu integraciju djece koja žive $\mathrm{u}$ istoj zajednici nije nikada provedena, nego je ostala u političkoj sferi, pa se stoga često javlja kao kontroverzno pitanje.

Sa stajališta integracijskih procesa djece koja pripadaju različitim etničkim skupinama, ali žive $\mathrm{u}$ istoj zajednici, postavlja se pitanje koliko ovakav oblik školovanja ostavlja djeci prostora za međugrupni kontakt, koji je pretpostavka međusobnog upoznavanja, stvaranja bliskijih vršnjačkih odnosa, a time i preduvjet za borbu protiv međugrupnih predrasuda. Ovo pitanje postaje još važnije ako se uzme u obzir da je škola kao prostor zapravo jedino okružje u kojem bi kontakt mogao biti najvjerojatniji, najprirodniji i s najvećim učinkom. Naime, u poslijeratnim okolnostima ove zajednice međuetnička se komunikacija uglavnom odvija na površnoj razini i visoko je kontrolirana unutargrupnim socijalnim pritiskom (Ajduković i Čorkalo Biruški, 2008.; Babić, 2008., 2010.; Čorkalo Biruški i Ajduković, 2008.a, 2008.b, 2012.a). U ovom radu ne postavljamo izravno pitanje o mogućnostima uzajamnih kontakata djece, pripadnika većine i manjine, nego njihov realitet, uz ostale varijable, istražujemo $\mathrm{u}$ okolnostima specifične (postkonfliktne) međuetničke situacije i školskoga konteksta.

Stoga je cilj ovoga istraživanja utvrditi mogućnost predviđanja stavova adolescenata prema svakodnevnoj integraci- 
DRUŠ. ISTRAŽ. ZAGREB GOD. 21 (2012), BR. 4 (118)

STR. $901-921$

ČORKALO BIRUŠKI, D., AJDUKOVIĆ, D.: ŠTO ODREĐUJ.: ji vršnjaka, pripadnika većinske i manjinske etničke grupe (Hrvata i Srba) u školskom kontekstu (stav prema školskoj integraciji) i izvan školskoga konteksta (stav prema socijalnoj integraciji) na temelju pet grupa prediktora - sociodemografskih varijabli dobi i spola, identitetnih varijabli nacionalnog identiteta i unutargrupne pristranosti, stava prema vrijednosti obrazovanja, međugrupnih stavova (stava prema multikulturnosti i stava prema asimilaciji) te međugrupnih bihevioralnih tendencija (sklonost diskriminiranju pripadnika vanjske grupe) i ponašanja (mjera kontakta s vršnjacima druge grupe). Naše su dosadašnje analize (Čorkalo Biruški i Ajduković, 2008.a; 2008.b; 2012.a) jasno pokazale da se djeca razlikuju u stavu prema školskom i socijalnom integriranju te da se može pretpostaviti kako će odabrani, koliko nam je poznato, jedinstveni niz stavovno-ponašajnih prediktora različito pridonositi predikciji ovih stavova. Osim toga, praćenje njihove prediktivne snage u dvije vremenske točke dat će informaciju o tome postaju li pojedini identitetni i ponašajni međugrupni aspekti s vremenom važniji ili manje važni u ovoj još uvijek etnički osjetno podijeljenoj sredini. Ovakav pristup nema samo teorijsko značenje rasvjetljavanja uloge pojedinih aspekata međugrupnih odnosa za integracijske stavove i, posebno, njihovu vremensku promjenu nego se ti podaci mogu i izravno praktično primijeniti u planiranju aktivnosti koje će potaknuti integracijske procese $\mathrm{u}$ zajednici.

\section{METODA}

\section{Sudionici i postupak}

Ovo je istraživanje provedeno 2001. i 2007. godine u vukovarskim osnovnim i srednjim školama u kojima se nastava provodi i na hrvatskom i na srpskom jeziku i pismu, u okviru redovite nastave. Učenici su ispunjavali upitnik na svojem materinskom jeziku, a za vrijeme ispitivanja u razredu je s njima bio/la samo ispitivač. Ispitivanje je trajalo oko jednoga školskog sata. U ispitivanju 2001. godine sudjelovalo je 718 učenika i učenica osnovnih (6. i 8. razred) i srednjih škola (2. razred). Primijenjen je probabilistički model klaster-uzorka i osigurana visoka reprezentativnost rezultata, pa su u konačnici uzorkom obuhvaćeni praktički svi učenici šestih i osmih razreda osnovnih škola u kojima je postojala nastava na oba jezika te $47 \%$ učenika drugih razreda srednjih škola u Vukovaru. Prosječna dob bila je $\mathrm{M}=14,18(\mathrm{SD}=1,718)$, a u uzorku je bilo $43 \%$ djevojaka.

U ispitivanju 2007. godine sudjelovala su 703 učenika i učenica osnovnih i srednjih škola u Vukovaru. Uz učenike šestog i osmog razreda osnovne škole te drugog razreda sred- 
DRUŠ. ISTRAŽ. ZAGREB GOD. 21 (2012)

BR. $4(118)$

STR. $901-921$

ČORKALO BIIRUŠKI, D.

AJDUKOVIĆ, D.:
ŠTO ODREĐUJE...

\section{Instrumenti}

nje škole, uključeni su i učenici 1. razreda srednje škole, odabrani po istom načelu. Uzorkom je obuhvaćeno $82 \%$ učenika 6. i 8. razreda vukovarskih osnovnih škola s dvojezičnom nastavom te $37 \%$ učenika 1. i 2 . razreda srednje škole. Prosječna dob bila je $\mathrm{M}=14,16(\mathrm{SD}=1,590)$, a u uzorku je bilo $47 \%$ djevojaka. ${ }^{2}$

U istraživanju je ispitano pet skupina varijabli: sociodemografske (spol i dob učenika), mjere identiteta (nacionalni identitet $^{3}$ i unutargrupna pristranost), stav prema obrazovanju kao životnoj vrijednosti, međugrupni stavovi (tolerancija na različitosti i stav prema asimilaciji nacionalnih manjina) te međugrupna ponašanja (međugrupni kontakt i sklonost diskriminaciji).

Nacionalni identitet izmjeren je skalom nacionalnog identiteta (NAIT) (Čorkalo i Kamenov, 2003.), koja sadrži 27 čestica uz koje sudionik iskazuje svoj stupanj slaganja od 1 (izrazito se ne slažem) do 5 (izrazito se slažem). Veći rezultat upućuje na izraženiji nacionalni identitet. Koeficijent nutarnje konzistencije $\mathrm{u}$ ovom je istraživanju iznosio $\alpha=0,90$. Primjeri čestica jesu: "Lojalnost vlastitoj naciji je važnija od lojalnosti samom sebi" te "Osjećaj vezanosti za vlastiti narod jedan je od najljepših osjećaja koje pojedinac može imati."

Unutargrupna pristranost izmjerena je kao razlika opće evaluacije vlastite grupe i vanjske grupe. Sudionici su procjenjivali kakav je njihov opći odnos prema vlastitom i drugom narodu (Srbima i Hrvatima) na skali od 0 (izrazito negativan) do 10 (izrazito pozitivan). Viši rezultat značio je veću unutargrupnu pristranost.

Stav prema obrazovanju kao životnoj vrijednosti izmjeren je skalom od 7 čestica, a sudionici su na skali od 1 do 4 izražavali svoj stupanj slaganja. Viši rezultat značio je pozitivniji stav prema obrazovanju kao životnoj vrijednosti. Skala je dobre pouzdanosti tipa nutarnje konzistencije $(\alpha=0,75)$, a primjer čestice glasi: "Školovanje će mi omogućiti da imam veći utjecaj u društvu". Njezin detaljniji prikaz, kao i prikaz drugih stavovnih mjera u ovom istraživanju, može se vidjeti u Corkalo Biruški i Ajduković, 2007. i 2012.b.

Tolerancija na (etničke) različitosti/stav prema multikulturalnosti ispitana je skalom od 9 čestica, dobre nutarnje konzistencija $(\alpha=0,76)$, a sudionici su izražavali svoj stupanj slaganja s česticama na skali od 1 do 4 . Viši rezultat znači veću toleranciju sudionika na različitosti. Primjer čestice glasi: "Svaka država je dužna brinuti se o pravima nacionalnih manjina".

Međugrupni kontakt izmjeren je pomoću čestice koja je pitala: "Kakav je tvoj osobni kontakt s pripadnicima druge grupe?" Odgovori su kodirani od 1 (nikakvi ili samo slučajni kontakti), 2 (poznanički kontakti) do 3 (prijateljski kontakti). 
DRUŠ. ISTRAŽ. ZAGREB GOD. 21 (2012), BR. $4(118)$

STR. $901-921$

ČORKALO BIRUŠKI, D., AJDUKOVIĆ, D.: ŠTO ODREĐUJE.
Sklonost diskriminaciji odmjerena je trima česticama $(\alpha=0,72)$, koje predstavljaju opise uobičajenih situacija u kojima se mladi svakodnevno nalaze, a koje sudionika stavljaju pred izbor odabira pripadnika vlastite grupe ili vanjske grupe. Sudionici su svoj odabir trebali deklarirati sa "da", ako bi nužno izabrali pripadnika svoje grupe, ili sa "ne", ako ne bi nužno odabrali pripadnika svoje grupe. Veći rezultat (veći broj "da" odgovora) upućuje na veću sklonost diskriminaciji, odnosno veću sklonost sudionika da u svakodnevnim situacijama nužno bira pripadnika vlastite grupe, čak i onda kada u opisanoj aktivnosti za to nema nikakva opravdanja. Primjer čestice glasi: "Da ja trebam odlučiti koji učenici će biti izabrani u školski sportski tim, ja bih između dva učenika izabrao Srbina/Hrvata, iako je malo slabiji sportaš."

Stav prema školskoj integraciji ispitan je skalom od 11 čestica, visoke nutarnje konzistencije $(\alpha=0,90)$, a sudionici su izražavali svoj stupanj slaganja s česticama na skali od 1 do 4 . Viši rezultat upućuje na pozitivniji stav prema integraciji djece i mladih u školskom okruženju. Primjer čestice glasi: "Srpska i hrvatska djeca trebaju ići zajedno u školu, jer će se tako upoznati i sprijateljiti."

Stav prema socijalnoj integraciji ispitan je skalom od 4 čestice, čija je pouzdanost tipa nutarnje konzistencije prihvatljiva $(\alpha=0,71)$, pri čemu je viši rezultat upućivao na pozitivniji stav prema druženju i socijalnoj integraciji djece i mladih izvan školskog okruženja. Primjer čestice glasi: "Ne bi me smetalo da moj dečko/djevojka bude srpske/hrvatske nacionalnosti."

Potonja dva stava - stav prema školskoj i socijalnoj integraciji - služila su kao dvije kriterijske varijable, rezultati kojih su predviđani na temelju navedenoga niza prediktora.

\section{REZULTATI}

Da bismo ispitali hipotezu da odabrani sklop prediktora - sociodemografske varijable dobi i spola, identitetne varijable nacionalnog identiteta i unutargrupne pristranosti, stav prema vrijednosti obrazovanja, međugrupni stavovi multikulturnosti $\mathrm{i}$ asimilacije, te međugrupne bihevioralne namjere i ponašanja izraženi kao vrsta kontakta s vanjskom grupom i sklonost njezine diskriminacije - predviđa stavove prema školskoj i socijalnoj integraciji, proveli smo niz višestrukih hijerarhijskih regresijskih analiza. Prediktorske varijable uvođene su u blokovima u pet koraka, slijedom kako su navedene. Hijerarhijsko uvođenje pojedinoga skupa prediktora omogućit će nam utvrđivanje nezavisnoga doprinosa varijabli za koje očekujemo da su teorijski relevantne u različitom stupnju. Tako je prediktorski sklop sociodemografskih varijabli vjerojatno najmanje prediktivan, no pretpostavljamo različitu prediktiv- 
(1) TABLICA 1 (A)

Koeficijenti korelacije prediktora i kriterija u većinskom i manjinskom uzorku 2001. godine (kurent) i 2007. godine (kurziv) nu snagu identitetnih varijabli kao posebnoga sklopa te mjera međugrupnih odnosa izmjerenih na dvije razine: na razini stavova i na razini ponašajnih namjera i ponašanja. Ukupno je provedeno osam regresijskih analiza, kojima je provjerena mogućnost predikcije stavova prema školskoj i socijalnoj integraciji kod većine i manjine 2001. i 2007. godine.

Korelacije svih uključenih prediktora i kriterijskih varijabli, te prosjeci i standardne devijacije, prikazane su u Tablici 1.

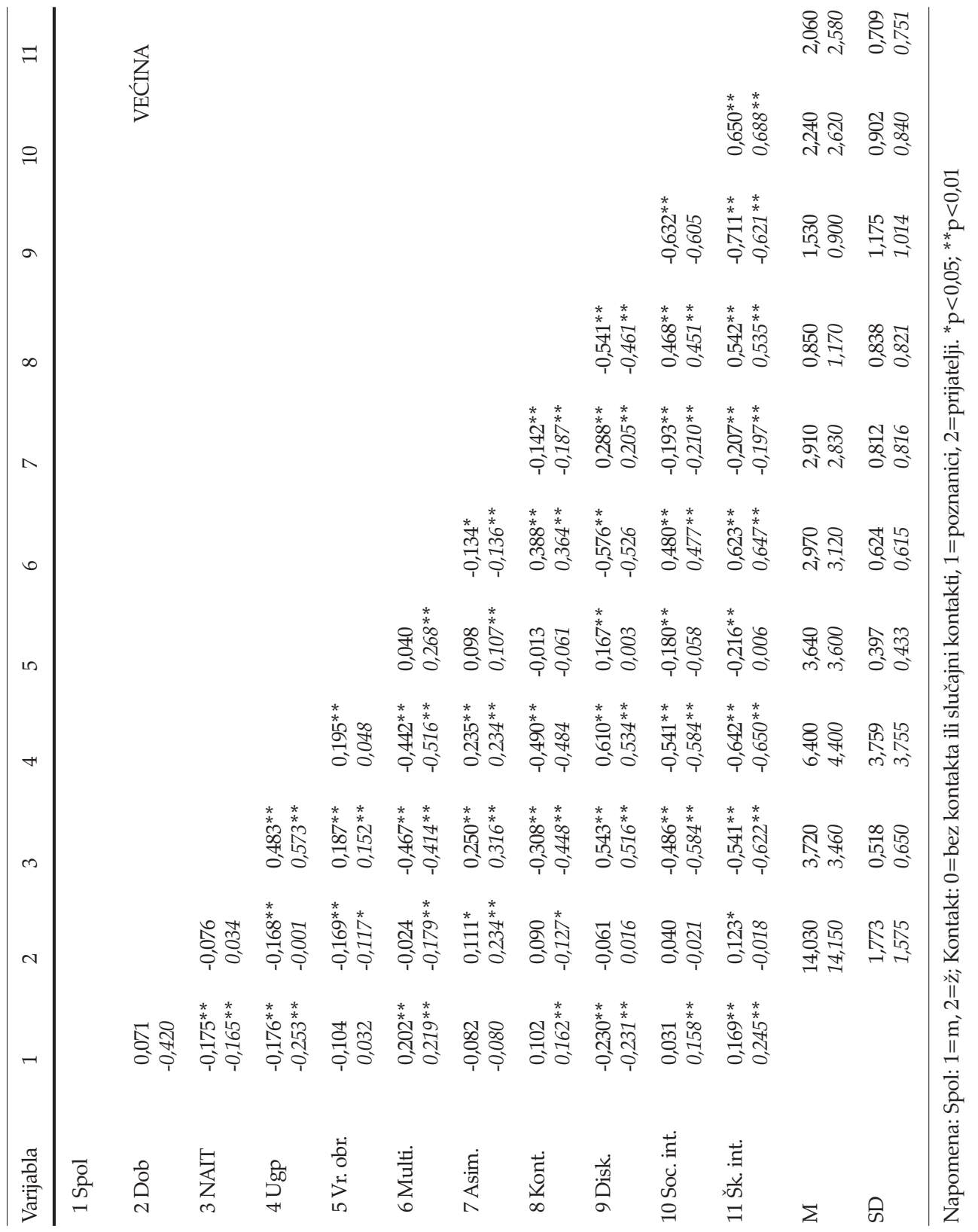




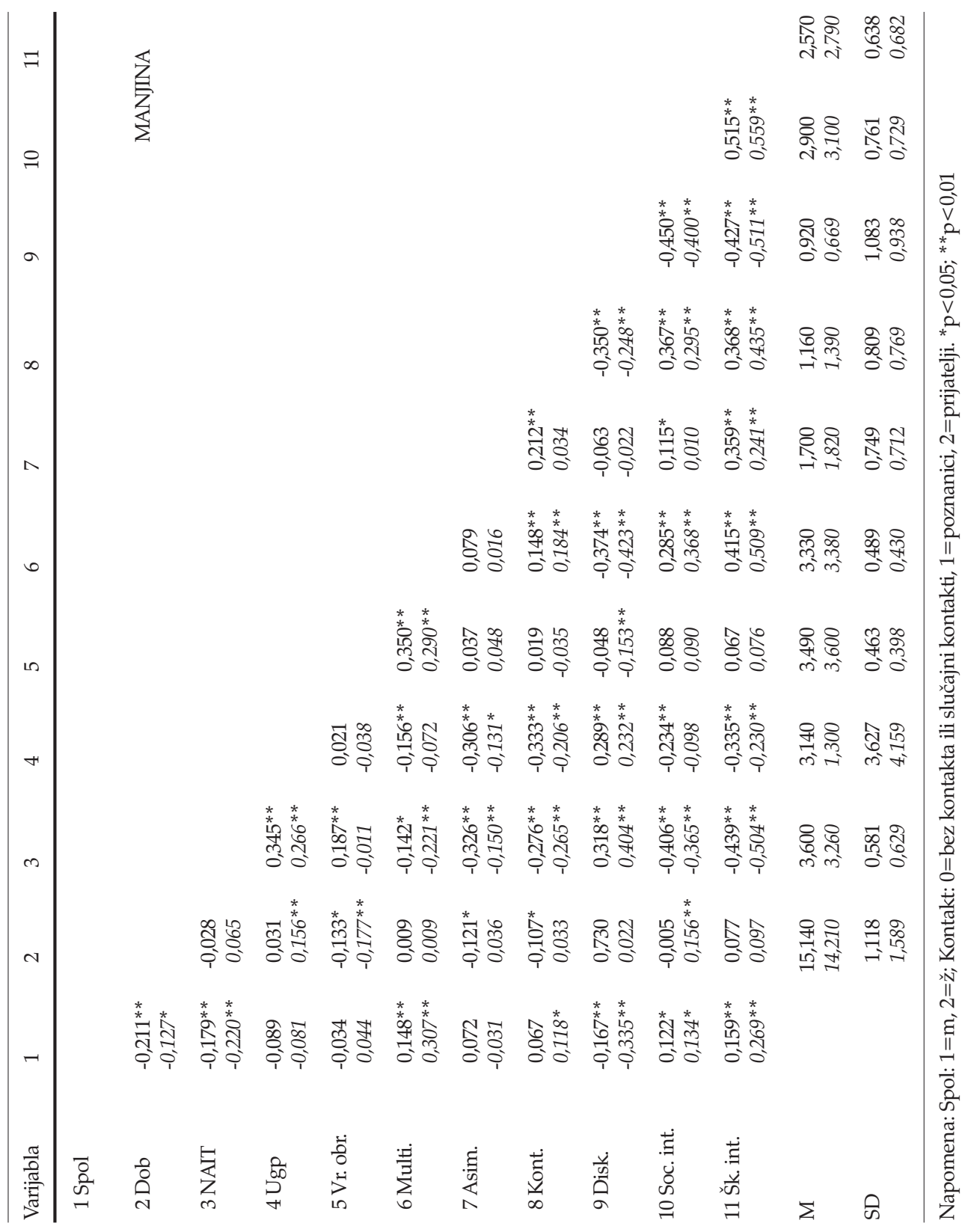

(1) TABLICA 1 (B) Koeficijenti korelacije prediktora i kriterija u većinskom i manjinskom uzorku 2001. godine (kurent) i

2007. godine (kurziv)

Rezultati hijerarhijskih regresijskih analiza prikazani su u Tablicama 2 i 3. U prvoj hijerarhijskoj regresijskoj analizi predviđan je kriterij stava prema školskoj integraciji u prvoj točki mjerenja, 2001. godine. Kada je riječ o pripadnicima većine, odabranim nizom prediktora objašnjeno je $66 \%$ varijance kriterija, pa oni dobro predviđaju stavove prema školskoj integraciji. Pri tome analiza snage prediktora $u$ posljednjem ko- 
DRUŠ. ISTRAŽ. ZAGREB GOD. 21 (2012),

BR. 4 (118)

STR. 901-921

ČORKALO BIRUŠKI, D., AJDUKOVIĆ, D.: ŠTO ODREĐUJE.

(1) TABLICA 2

Sažetak hijerarhijske regresijske analize (standardizirani regresijski koeficijenti B) za varijable koje predviđaju stav prema školskoj integraciii diece u Vukovaru $(\mathrm{N}=316$ za većinu $\mathrm{i}$ $\mathrm{N}=235$ za manjinu 2001.; $\mathrm{N}=354 \mathrm{za}$ većinu i $\mathrm{N}=296 \mathrm{za}$ manjinu 2007. . raku rasvjetljuje njihov konačni doprinos objašnjavanju varijance kriterija: kao značajni prediktori u prvoj točki mjerenja izdvajaju se identitetne varijable (nacionalni identitet $\beta=-0,09$, $p<0,001$; unutargrupna pristranost $\beta=-0,22, p<0,01$ ), stav prema obrazovanju kao značajnoj životnoj vrijednosti $(\beta=-0,12$, $\mathrm{p}<0,001)$, tolerancija prema različitostima/multikulturnost iz sklopa međugrupnih stavova $(\beta=0,30, \mathrm{p}<0,001)$, te međugrupna ponašanja (vrsta kontakta s pripadnicima vanjske grupe $\beta=0,15, \mathrm{p}<0,001$; sklonost diskriminaciji $\beta=-0,26, \mathrm{p}<0,001)$. Isti prediktori, uz iznimku stava prema obrazovanju kao životnoj vrijednosti, predviđaju ovu kriterijsku varijablu i u drugoj točki mjerenja s jednakom snagom - objašnjavaju visokih $67 \%$ varijance kriterija. Identitetne varijable ostaju visoko značajni prediktori, pri čemu nacionalni identitet postaje još snažniji prediktor $(\beta=-0,23, p<0,001)$, a unutargrupna pristranost nešto slabiji, ali još uvijek visoko značajan $(\beta=-0,19, p<0,001)$. Stav prema toleranciji ostaje značajan prediktor $(\beta=0,34, p<0,001)$, kao i varijable međugrupnoga ponašanja (vrsta kontakta s pripadnicima vanjske grupe $\beta=0,14, \mathrm{p}<0,001$; sklonost diskriminaciji $\beta=-0,15, p<0,01)$.

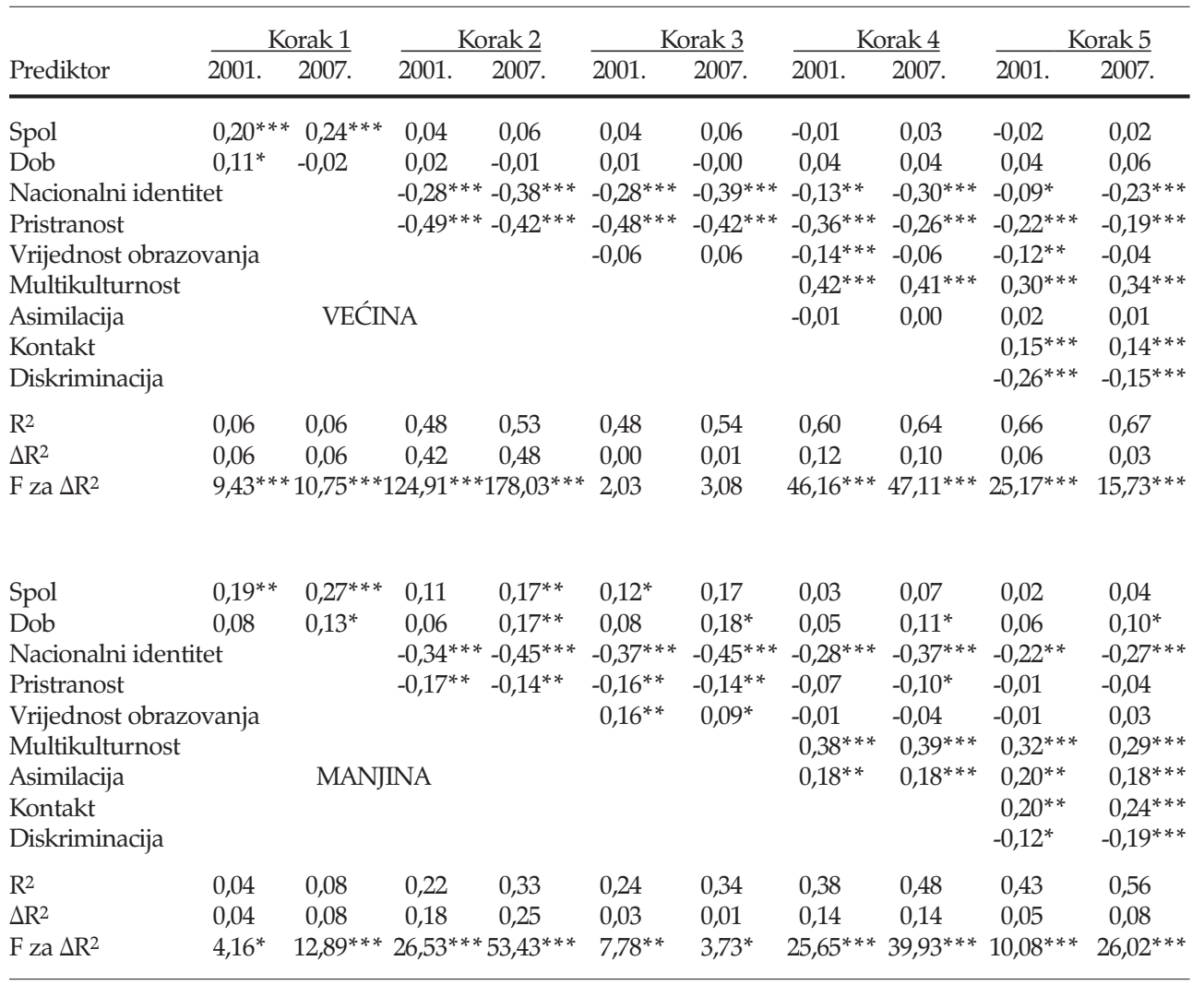

${ }^{*} \mathrm{p}<0,05 ;{ }^{* *} \mathrm{p}<0,01 ;{ }^{* *} \mathrm{p}<0,001$ 


\begin{tabular}{|c|c|c|c|c|c|c|c|c|c|c|}
\hline \multirow[b]{2}{*}{ Prediktor } & \multicolumn{2}{|c|}{ Korak 1} & \multicolumn{2}{|c|}{ Korak 2} & \multicolumn{2}{|c|}{ Korak 3} & \multicolumn{2}{|c|}{ Korak 4} & \multicolumn{2}{|c|}{ Korak 5} \\
\hline & 2001. & 2007. & 2001. & 2007. & 2001. & 2007. & 2001. & 2007. & 2001. & 2007. \\
\hline Spol & 0,07 & $0,16^{*}$ & $-0,07$ & $-0,01$ & $-0,08$ & $-0,00$ & $-0,11^{*}$ & $-0,02$ & $-0,13^{*}$ & $-0,04$ \\
\hline Dob & 0,03 & $-0,02$ & $-0,06$ & $-0,02$ & $-0,07$ & $-0,02$ & $-0,05$ & $-0,01$ & $-0,05$ & 0,01 \\
\hline Nacionalni identi & & & $-0,27^{* * *}$ & $-0,36^{* * *}$ & $-0,27^{* * *}$ & $-0,36^{* * *}$ & $-0,16^{* *}$ & $-0,31^{* * *}$ & $-0,12^{*}$ & $-0,23^{* * *}$ \\
\hline Pristranost & & & $-0,43^{* * *}$ & $*-0,38^{* * *}$ & $-0,43^{* * *}$ & $-0,38^{* * *}$ & $-0,34^{* * *}$ & $-0,29 * * *$ & $-0,19 * *$ & $-0,22 *$ \\
\hline Vrijednost obrazo & vanja & & & & $-0,07$ & 0,02 & $-0,13^{* *}$ & $-0,05$ & $-0,11^{*}$ & $-0,03$ \\
\hline Multikulturnost & & & & & & & $0,31^{* * *}$ & $0,24^{* * *}$ & $0,18^{* *}$ & $0,14^{*}$ \\
\hline Asimilacija & & VEĆl & NA & & & & 0,00 & 0,01 & 0,03 & 0,02 \\
\hline Kontakt & & & & & & & & & $0,13^{* *}$ & 0,07 \\
\hline Diskriminacija & & & & & & & & & $-0,29 * * *$ & $-0,27^{* * *}$ \\
\hline $\mathrm{R}^{2}$ & 0,01 & 0,03 & 0,36 & 0,44 & 0,36 & 0,44 & 0,43 & 0,47 & 0,49 & 0,52 \\
\hline$\Delta \mathrm{R}^{2}$ & 0,01 & 0,03 & 0,35 & 0,41 & 0,00 & 0,00 & 0,06 & 0,03 & 0,06 & 0,05 \\
\hline $\mathrm{F} \Delta \mathrm{R}^{2}$ & 1,01 & $4,82^{*}$ & $85,79 * * *$ & $126,80^{* * *}$ & 2,49 & 0,24 & $17,22^{* * *}$ & $11,12^{* * *}$ & $18,22^{* * *}$ & $17,65^{* * *}$ \\
\hline Spol & 0,10 & $0,14^{*}$ & 0,02 & 0,06 & 0,03 & 0,06 & $-0,00$ & $-0,02$ & $-0,02$ & $-0,05$ \\
\hline Dob & 0,03 & $0,18^{* *}$ & 0,00 & $0,21^{* * *}$ & 0,02 & $0,23^{* *}$ & $-0,02$ & $0,19^{* * *}$ & $-0,01$ & $0,17^{* * *}$ \\
\hline Nacionalni identi & & & $-0,37^{* * *}$ & $-0,37^{* * *}$ & $-0,40^{* * *}$ & $-0,37^{* * *}$ & $-0,44^{* * *}$ & $-0,33^{* * *}$ & $-0,33^{* * *}$ & $-0,25^{* * *}$ \\
\hline Pristranost & & & $-0,09$ & $-0,05$ & $-0,08$ & $-0,04$ & $-0,06$ & $-0,03$ & $-0,02$ & $-0,00$ \\
\hline Vrijednost obrazo & vanja & & & & $0,13^{*}$ & $0,10^{*}$ & 0,06 & 0,01 & 0,07 & 0,02 \\
\hline Multikulturnost & & & & & & & $0,20^{* *}$ & $0,30^{* * *}$ & 0,08 & $0,22^{* * *}$ \\
\hline Asimilacija & & MAN & INA & & & & $-0,16^{*}$ & $-0,03$ & $-0,11$ & $-0,03$ \\
\hline Kontakt & & & & & & & & & $0,17^{* *}$ & $0,14^{* *}$ \\
\hline Diskriminacija & & & & & & & & & $-0,29 * * *$ & $-0,16^{* *}$ \\
\hline $\mathrm{R}^{2}$ & 0,01 & 0,05 & 0,17 & 0,19 & 0,19 & 0,20 & 0,24 & 0,27 & 0,34 & 0,31 \\
\hline$\Delta \mathrm{R}^{2}$ & 0,01 & 0,05 & 0,16 & 0,14 & 0,02 & 0,01 & 0,05 & 0,07 & 0,10 & 0,04 \\
\hline $\mathrm{F} \Delta \mathrm{R}^{2}$ & 1,10 & $7,43^{* *}$ & $22,29 * * *$ & $* 25,26^{* * *}$ & $4,66^{*}$ & $3,68^{*}$ & $7,95^{* * *}$ & $13,96^{* * *}$ & $16,20^{* * *}$ & $7,94^{* * *}$ \\
\hline
\end{tabular}

${ }^{*} \mathrm{p}<0,05 ;{ }^{* *} \mathrm{p}<0,01 ;{ }^{* * *} \mathrm{p}<0,001$

(1) TABLICA 3

Sažetak hijerarhiijske regresijske analize (standardizirani regresijski koeficijenti B) za varijable koje predviđaju stav prema socijalnop integraciii diece u Vukovaru $(\mathrm{N}=316$ za većinu $\mathrm{i}$ $\mathrm{N}=235$ za manjinu 2001.; $\mathrm{N}=354 \mathrm{za}$ većinu i $\mathrm{N}=296 \mathrm{za}$ manjinu 2007.)
Kada je riječ o uzorku manjine, stav prema školskoj integraciji predviđaju uglavnom iste varijable kao i kod većine, ali s manjom snagom. U prvom mjerenju, 2001. godine, objašnjeno je $43 \%$ varijance stava prema školskoj integraciji, pri čemu su u zadnjem koraku jednadžbe značajnima ostali nacionalni identitet $(\beta=-0,22, p<0,01)$; međugrupna tolerancija $(\beta=0,32$, $\mathrm{p}<0,001)$, ali i sklonost asimilaciji $(\beta=0,20, \mathrm{p}<0,01)$, te međugrupna ponašanja (vrsta kontakta $\beta=0,20, p<0,01$ i sklonost diskriminaciji $\beta=-0,12, p<0,05)$. Odabrani prediktori nešto bolje predviđaju stav prema školskoj integraciji u manjinskom uzorku u drugom mjerenju - objašnjeno je 56\% varijance kriterija, za $13 \%$ više nego u prvom mjerenju, no za $11 \%$ manje nego u uzorku većine. Veličine beta-koeficijenata ostaju uglavnom podjednake kao i u mjerenju 2001. godine (Tablica 2).

U sljedećem nizu hijerarhijskih jednadžba na temelju istih prediktora predviđan je stav prema socijalnoj integraciji. Na uzorku većinske djece u mjerenju 2001. godine uključenim je prediktorima objašnjeno $49 \%$ varijance kriterija, a u zadnjem su koraku jednadžbi značajno pridonijeli spol sudionika $(\beta=-0,12, p<0,05)$, nacionalni identitet $(\beta=-0,12, p<0,05)$ i 
DRUŠ. ISTRAŽ. ZAGREB GOD. 21 (2012) BR. $4(118)$

STR. $901-921$

ČORKALO BIIRUŠKI, D., AJDUKOVIĆ, D.: ŠTO ODREĐUJE.

unutargrupna pristranost $(\beta=-0,19, \mathrm{p}<0,01)$, ali i vrijednost obrazovanja $(\beta=-0,11, p<0,05)$, tolerancija prema različitostima $(\beta=0,18, p<0,01)$ te međugrupna ponašanja - kontakti s vanjskom grupom $(\beta=0,13, \mathrm{p}<0,01)$ i diskriminacijske tendencije $(\beta=-0,29, p<0,01)$. Šest godina kasnije, 2007., isti sklop prediktora tumači neznatno više varijance kriterija, $52 \%$, a struktura značajnih prediktora $\mathrm{u}$ zadnjem se koraku analize neznatno mijenja. Spol se više ne javlja kao značajan prediktor $(p>0,05)$, kao ni vrijednost obrazovanja $(p>0,05)$, a značajnima ostaju varijable identiteta (nacionalni identitet $\beta=-0,23$, $p<0,01$ i unutargrupna pristranost $\beta=-0,22, p<0,01$ ), neki međugrupni stavovi (tolerancija prema različitostima $\beta=0,14$, $p<0,05)$ i međugrupna ponašanja (diskriminacijske tendencije, $\beta=-0,27, p<0,001)$.

Na uzorku manjine odabrani prediktori nešto slabije predviđaju i stav prema socijalnoj integraciji nego kod većine te tumače 34\% varijance u mjerenju 2001. i 31\% varijance u mjerenju 2007. godine. U prvom mjerenju u zadnjem koraku jednadžbe značajni ostaju prediktori nacionalnog identiteta $(\beta=-0,33$, $\mathrm{p}<0,01)$ te mjere kontakta $(\beta=0,17, \mathrm{p}<0,01)$ i diskriminacije $(\beta=-0,29, p<0,001)$. U mjerenju 2007. u uzorku manjine stav prema socijalnoj integraciji značajno tumače prediktori dobi $(\beta=0,17, \mathrm{p}<0,01)$, nacionalnog identiteta $(\beta=-0,25, \mathrm{p}<0,001)$, stav tolerancije na različitosti $(\beta=0,22, \mathrm{p}<0,001)$, kontakti $\mathrm{s}$ vanjskom grupom $(\beta=0,14, p<0,01)$ te sklonost diskriminaciji $(\beta=-0,16, p<0,01)$.

\section{RASPRAVA}

Cilj ovoga istraživanja bio je ispitati mogućnost predikcije stavova prema školskoj i socijalnoj integraciji adolescenata, u kontekstu podijeljene zajednice u dvije vremenske točke. Naglašavajući važnost i istaknutost etničkih identiteta u socijalnoj okolini u kojoj djeca žive te ograničenu mogućnost međuetničkih kontakata zbog specifičnoga načina organizacije školovanja, pretpostavljeno je da će varijable kojima je opisana društvena realnost djece - sociodemografske karakteristike, identitetne varijable, stav prema vrijednosti obrazovanja, međuetnički stavovi i međuetnička ponašanja - biti dobri prediktori dvaju kriterijskih stavova u obje točke vremena. Pri tome pretpostavka o vremenskoj promjeni sklopa prediktora nije izrijekom postavljena, premda impliciramo da situacija odijeljenoga školovanja i odsutnost aktivnoga napora u međusobnom približavanju dviju najvećih etničkih grupa nije kontekst $\mathrm{u}$ kojem bi se očekivale bitne promjene tijekom vremena (usp. Čorkalo Biruški i Ajduković, 2012.a).

Rezultati višestruke hijerarhijske regresijske analize potvrdili su pretpostavku o prediktivnoj snazi uključenih varijabli, premda je njihova konačna struktura donekle različita u 
DRUŠ. ISTRAŽ. ZAGREB GOD. 21 (2012),

BR. $4(118)$

STR. $901-921$

ČORKALO BIRUŠKI, D., AJDUKOVIĆ, D.: ŠTO ODREĐUJE. dvije vremenske točke i u uzorku većine i manjine. Dva su nalaza ključna: prvo, odabrani prediktori bolje predviđaju stavove prema školskoj nego prema socijalnoj integraciji, što vrijedi i za većinu i za manjinu. Drugo, odabrani prediktori bolje predviđaju obje grupe stavova kod većine nego kod manjine.

Pokazalo se da sociodemografske varijable nisu relevantan prediktor integracijskih stavova, barem kada je o mladima riječ, no uz dvije iznimke: spol je bio značajan prediktor stava prema socijalnoj integraciji kod većine u prvom mjerenju, $i$ to tako da su djevojke iskazivale pozitivnije stavove. Doprinos spola ne pojavljuje se više kao značajan ni za drugi kriterij, ni u drugim uzorcima, pa je opravdano pretpostaviti da nema značajnu ulogu kao odrednica stava prema socijalnoj i školskoj integraciji. Dob se također pojavljuje kao značajan prediktor stava i prema socijalnoj i prema školskoj integraciji, ali samo na manjinskom uzorku. Budući da se ova pravilnost ne javlja i kod većine, nije vjerojatno da je riječ o očekivanom razvojnom trendu pozitivnijih integracijskih stavova kod starije djece. Recentna metaanalitička studija Raabea i Beelmanna (2011.) pokazuje da, čini se, u međugrupnim stavovima nema sustavnih razlika u razdoblju adolescencije, što je dobni uzorak i u našem istraživanju. Stoga je vjerojatno da je riječ o specifičnim povezanostima ove varijable s drugim prediktorima u manjinskom uzorku, barem kada je riječ o stavu prema školskoj integraciji. Naime, kako se iz matrice bivarijatnih korelacija vidi (Tablica 1), dob nije značajno povezana sa stavom prema školskoj integraciji ni u jednom mjerenju. U pogledu stava prema socijalnoj integraciji, stariji ispitanici u drugom mjerenju pokazuju pozitivniji stav. Moguće je da je ovdje riječ o specifičnim kontekstualnim okolnostima: starija manjinska djeca imaju više integracijskih prilika s pripadnicima većine i u raznolikijim socijalizacijskim okolnostima nego mlađa, pa je moguće da to utječe na usvajanje pozitivnijih stavova prema socijalnoj integraciji.

Prediktori uvedeni u drugom koraku - nacionalni identitet i unutargrupna pristranost - najbolje predviđaju oba integracijska stava, barem kod većine. Nacionalni identitet je i u manjinskom uzorku najvažniji prediktor integracijskih stavova. Značajno je prokomentirati da uvođenje identitetnih varijabli (u 2. koraku) donosi najveći skok u objašnjenoj varijanci kriterija socijalne integracije u oba uzorka; $\mathrm{u}$ većinskom $\mathrm{u}$ zorku taj skok u prvom mjerenju iznosi 35\%, a u drugom čak $41 \%$. Postotak objašnjene varijance ne raste toliko u manjinskom uzorku, no također je najveći - 16\% u prvom, odnosno $14 \% \mathrm{u}$ drugom mjerenju. Za kriterij školske integracije identitetne varijable donose skok od čak $42 \%$ objašnjene varijance u prvom i $48 \%$ varijance u drugom mjerenju. Kod manjine, ti su doprinosi manji, ali također relativno najveći u ovom prediktorskom sklopu - $18 \%$ u prvom i $25 \%$ u drugom mjerenju. 
DRUŠ. ISTRAŽ. ZAGREB GOD. 21 (2012)

BR. $4(118)$

STR. $901-921$

ČORKALO BIIRUŠKI, D., AJDUKOVIĆ, D.: ŠTO ODREĐUJE.
U većinskom uzorku pozitivnije integracijske stavove imaju osobe manje izraženoga nacionalnog identiteta i manje izražene unutargrupne pristranosti. U manjinskom uzorku taj se odnos potvrđuje za varijablu nacionalnog identiteta, ali ne i za unutargrupnu pristranost. Ovi rezultati jasno pokazuju važnost identitetnih varijabli kao odrednicu integracijskih stavova u oba uzorka - sudionici koji imaju niži nacionalni identitet i, kada je riječ o većini, nižu unutargrupnu pristranost, skloniji su i socijalnoj i školskoj integraciji sa svojim vršnjacima iz druge grupe. Dobiveni su nalazi sasvim u skladu s predikcijama teorije socijalnoga identiteta (Tajfel i Turner, 1986.) - u uvjetima visoke salijentnosti grupne pripadnosti, o kakvoj je riječ u našem uzorku - identifikacija s grupom snažno oblikuje odnos prema vanjskoj grupi (Brewer, 2001.; Doosje i sur., 1999.; Hewstone i sur., 2002.). Štoviše, grupe visokoga statusa pokazuju veću unutargrupnu pristranost od grupa niskoga statusa (Mullen i sur., 1992.; Jackson, 2002.; Verkuyten i Reijerse, 2008.), pa valja pretpostaviti da i ta činjenica pridonosi da kod većinske grupe i izraženiji identitet i unutargrupna pristranost predstavljaju značajne odrednice nepodržavanja integracijskih stavova. Posebno valja istaknuti da se identitetne varijable pokazuju snažnijim prediktorima školskih integracijskih stavova nego socijalnointegracijskih, što govori o snažnom identitetnom značenju škole u ovom specifičnom kontekstu. O toj činjenici treba voditi računa u kreiranju obrazovnih politika, posebno onih koje se tiču manjinskoga obrazovanja.

Vrijednost obrazovanja, suprotno očekivanjima, nije u završnoj jednadžbi značajan prediktor, osim u prvom mjerenju za većinsku grupu, i to za oba integracijska stava (premda je njezino samostalno uvođenje objasnilo (malen) dio varijance integracijskih stavova, ali samo u manjinskom uzorku). No smjer ove povezanosti nije očekivan: pokazuje se da su većinska djeca koja imaju manje pozitivan stav prema obrazovanju kao životnoj vrijednosti sklonija integraciji. Je li ovaj rezultat uvjetovan činjenicom da je 2001. godine pitanje odijeljenih škola djece bilo još vrlo vruće političko pitanje, ostaje na razini spekulacije. Čini se da s vremenom ova dva pitanja - vrijednost obrazovanja i pitanje integracije - ostaju odijeljena i kod većinske i kod manjinske djece. U prilog tim nalazima govore i naši kvalitativni podaci: dok su 2001. godine i roditelji i djeca, ali i nastavnici, bili zaokupljeni pitanjima stroge odijeljenosti škola i identitetnim implikacijama te podjele, šest godina kasnije ponajprije naglašavaju pitanje kvalitetnog obrazovanja, što je značajna zajednička polazišna osnova (Čorkalo Biruški i Ajduković, 2009.). Ovaj je pomak sasvim u skladu s nalazima u drugim europskim zemljama, koji, u kontekstu manjinsko-većinskih odnosa, također pokazuju istaknutost vrijednosti obrazovanja po sebi. Nedavno završena europska 
DRUŠ. ISTRAŽ. ZAGREB GOD. 21 (2012), BR. $4(118)$

STR. $901-921$

ČORKALO BIRUŠKI, D. AJDUKOVIĆ, D.: ŠTO ODREĐUJE.:. studija koja je uspoređivala poziciju djece i mladih, pripadnika većine u devet zemalja EU-a i pripadnika manjina druge generacije doseljenika (Szalai, 2011.) pokazuje da prepoznatost vrijednosti obrazovanja kao glavnoga pokretača vertikalne mobilnosti pojedinca $\mathrm{u}$ društvu postaje "opća norma $\mathrm{u}$ Europi" (str. 15).

Dva aspekta međugrupnih stavova, posebno značajnih u kontekstu manjinsko-većinskih odnosa - stav prema multikulturnosti i stav prema asimilaciji - na različit način određuju integracijske stavove. I manjinska i većinska djeca pozitivnijega stava prema multikulturnosti imaju i pozitivnije integracijske stavove. Stav prema asimilaciji manjina, međutim, ne pridonosi značajno integracijskim stavovima većine, ali je relevantna odrednica stava prema školskoj, no ne i stava prema socijalnoj integraciji kod manjine. Tako su školskoj integraciji sklonija manjinska djeca pozitivnijega stava prema asimilaciji manjina. Čini se, dakle, da je usvojenost pozitivnoga stava prema etničkoj raznolikosti važnija determinanta integracijskih stavova nego stav prema asimilaciji manjina. No kod manjine stav prema asimilaciji nije nevažna odrednica stava prema školskoj integraciji, pa i ovaj nalaz govori o identitetnom značaju škole. I premda stav prema multikulturnosti u višeetničkim zajednicama može imati veće socijalno značenje za manjinu nego za većinu (Verkuyten, 2005.b, 2008.), naši rezultati pokazuju da pozitivan stav prema višeetničnosti i kod većine i kod manjine pridonosi i pozitivnijem stavu prema socijalnoj i školskoj integraciji. Pri tome je stav multikulturnosti bolji prediktor školske nego socijalne integracije, a njegovo uključivanje u regresijsku jednadžbu objašnjava između 10 i 14\% varijance, čineći ga drugom najvažnijom odrednicom stava prema školskoj integraciji. Tome je tako i u manjinskom i u većinskom uzorku. Stoga važnost stava prema toleranciji etničkih manjina valja uzeti u obzir u svakoj ozbiljnoj inicijativi koja bi bila usmjerena na približavanje grupa u zajednici i poboljšavanje međuetničkih odnosa. Odgajanje i njegovanje multikulturnosti kao vrijednosti zajednice značajno može pomoći u tom zadatku.

Zadnji sklop prediktora - kontakt s vanjskom grupom i sklonost njezinoj diskriminaciji - značajni su prediktori integracijskih stavova i objašnjavaju između 3 i 10\% stavova, i to više kod manjine. Očekivano i u skladu s teorijom kontakta (Allport, 1954.; Pettigrew i Tropp, 2011.), djeca prisnijih kontakata s vanjskom grupom i manje sklona diskriminaciji imaju i pozitivnije stavove prema školskoj i izvanškolskoj međuetničkoj integraciji. No kada je riječ o socijalnoj integraciji kod većine, kontakt $\mathrm{u}$ drugom mjerenju prestaje biti značajan prediktor, ali ostaje značajna (ne)sklonost diskriminaciji. Iz tih nalaza ne treba zaključiti da kontakt prestaje biti važna odrednica integracijskih stavova kod većine. Prije će biti da je zbog 
DRUŠ. ISTRAŽ. ZAGREB GOD. 21 (2012)

BR. $4(118)$

STR. $901-921$

ČORKALO BIIRUŠKI, D., AJDUKOVIĆ, D.: ŠTO ODREĐUJE... visoke povezanosti varijabla kontakta i diskriminacije (i to veće nego u uzorku manjine), varijabla diskriminacije "odnijela" i dio varijance kontakta u ukupnom određenju stava prema socijalnoj integraciji. Važnost kontakta u borbi protiv predrasuda, i to čak veću za većinu nego za manjinu, potvrđuju nalazi u mnogim drugim multikulturnim sredinama (Wright $\mathrm{i}$ Tropp, 2005.; Tropp i Pettigrew, 2005.; Verkuyten, 2008.; Tropp i Prenovost, 2008.). I dok, u našem kontekstu, izvanškolska sredina daje većinskoj djeci više prilika da svoj socijalni krug odabiru unutar vlastite etničke grupe (pa kontakt onda za socijalnointegracijske stavove prestaje biti ključna odrednica), u školskom okružju kontakt i dalje značajno određuje stav prema školskoj integraciji. A upravo je škola sredina u kojoj djeca mogu doći u kontakt: bez prisile, u prirodnom okruženju, mogu stvarati kontakte koji će biti motivirani svim elementima na temelju kojih se i inače sklapaju vršnjačka prijateljstva, u sredinama koje nisu opterećene etničkom pripadnošću u socijalnoj dinamici zajednice. Čini se da i ovi nalazi upućuju na važnost smislenoga kontakta u poboljšanju međugrupnih odnosa, ostvarenog u optimalnim uvjetima. Pri tome, kako to pokazuju istraživanja i u europskom kontekstu, ključnu ulogu ima kvaliteta, a ne samo učestalost kontakta (Binder i sur., 2009.; Vervoort i sur., 2011.).

Ovaj rad upućuje na dosljednu i veliku važnost varijabli identiteta i međugrupnih ponašanja - kontakta i sklonosti diskriminaciji - u razumijevanju međugrupnih integracijskih stavova manjine $\mathrm{i}$ većine $\mathrm{u}$ specifičnom kontekstu podijeljene zajednice. Ističe se nalaz da u uvjetima etničke podijeljenosti varijable identiteta i kod većine i kod manjine snažno oblikuju integracijske stavove i da one, čini se, s vremenom postaju sve važnije, premda je plauzibilno očekivati da protok vremena smanjuje etničke napetosti i u prvi plan stavlja neke druge elemente socijalne dinamike zajednice. Snagu dobivenih nalaza svakako bi valjalo provjeriti u usporedivim socijalno-političkim kontekstima, ali i daljnjim vremenskim praćenjem promjena u samoj ciljnoj zajednici. Valja, također, upozoriti da je nacrt ovoga istraživanja korelacijski i da ne omogućuje donošenje zaključaka o uzročno-posljedičnim vezama između prediktorskih varijabli i kriterija. Ipak, praćenje rezultata u dvije vremenske točke i $\mathrm{u}$ dvije kohorte sudionika u dobi od 12 do 16 godina u Vukovaru daje istraživanju posebnu prednost i učvršćuje mogućnost donošenja zaključaka o vezama identiteta, međugrupnih ponašanja i međugrupnih stavova.

Stoga valja istaknuti sljedeće važne nalaze: najvažnija odrednica stavova prema školskoj i socijalnoj integraciji i za većinu i za manjinu jest izraženost nacionalnog identiteta, a identitetne varijable posebno dobro objašnjavaju stavove prema školskoj integraciji. Škola se, dakle, i kod većine i kod manjine javlja kao prostor iskazivanja etničkog identiteta, pa je 
DRUŠ. ISTRAŽ. ZAGREB GOD. 21 (2012),

BR. $4(118)$

STR. $901-921$

ČORKALO BIRUŠKI, D., AJDUKOVIĆ, D.: ŠTO ODREĐUJ.: onda školu moguće iskoristiti i kao prostor u kojem će socijalni identitet (ne jedan, nego mnogi i višestruki) biti njegovan i odgajan tako da to odgovara potrebama i realnosti multietničke, ali ne i podijeljene zajednice. Salijentnost identiteta $\mathrm{u}$ školskim se uvjetima očito ne može izbjeći - mladi se, idući u odijeljene razrede, suprotne smjene ili prostorno odijeljene okoline ne susreću drugačije osim kao "mi" i "oni". No identitet je moguće učiniti saveznikom u osmišljavanju programa integriranja zajednice temeljenih na mnogostrukim prilikama za ravnopravni kontakt koje vode ostvarivanju zajedničkih interesa mladih. Kako suvremena longitudinalna istraživanja pokazuju, (odgovarajući) kontakt smanjuje predrasude (a ne obratno!) (Brown i sur., 2007.), osobito kod većine. Kod manjine učinkovitost kontakta određuje činjenica je li pripadnik većinske grupe percipiran kao tipičan član (Binder i sur., 2009.). Također, različita prediktivna snaga odrednica integracijskih stavova kod većine i manjine nameće potrebu da se odgovori i na pitanje je li ovakav obrazac univerzalan u odnosima većine i manjine ili je tipičan i vremenski razmjerno stabilan samo u etnički podijeljenoj sredini. Važnost međugrupnih ponašajnih aspekata upućuje i na pravac mogućega djelovanja u smjeru integracije adolescenata, ali i čitave zajednice - kontakt i antidiskriminacijske mjere mogu značajno pridonijeti smanjivanju predrasuda i povećanju kohezije (Binder i sur., 2009.; Brown i sur., 2007.; Szalai, 2011.; Vermeij i sur., 2009.). Činjenica da međuetnički stavovi i ponašanja ostaju snažan prediktorski sklop za stavove prema socijalnoj, ali još više prema školskoj, integraciji stavlja podijeljenu zajednicu Vukovara pred posebno važne izazove - kako školsko okružje učiniti mjestom njegovanja identiteta koji neće biti (samo) ekskluzivan nego i inkluzivan i integrirajući te kako izvanškolske aktivnosti, manje identitetno opterećene, učiniti mogućim prostorom promjene i pozitivnih međuetničkih kontakata. Izgrađujući takvo socijalno tkivo, zasnovano na čvrstim socijalnim mrežama, zajednica si može osigurati ne samo stabilnu sadašnjost nego i izgraditi snažan faktor otpornosti za krizna vremena.

\section{BILJEŠKE}

${ }^{1}$ Kasnije je ovo pravo dodatno osnaženo Zakonom o odgoju i obrazovanju na jeziku i pismu nacionalnih manjina iz 2000. godine ( $\mathrm{Na}$ rodne novine, 51/2000.) te Ustavnim zakonom o pravima nacionalnih manjina iz 2002. godine (Narodne novine, 152/02.).

2 Detaljniji prikaz cjelokupnog uzorka $u$ oba vala istraživanja može se naći u Corkalo Biruški i Ajduković, 2008.a.

${ }^{3} \mathrm{U}$ ovom je radu za mjerenje vezanosti i odanosti vlastitoj nacionalnoj grupi (narodu!) uzeta skala nacionalnog identiteta (Čorkalo i Kamenov, 2003.), pa zadržavamo naziv nacionalni identitet za as- 
DRUŠ. ISTRAŽ. ZAGREB GOD. 21 (2012),

BR. $4(118)$

STR. 901-921

ČORKALO BIIRUŠKI, D., AJDUKOVIĆ, D.: ŠTO ODREĐUJE pekt socijalnog identiteta koji smo zahvatili. Naime, riječ je o doživljaju pripadnosti grupi, s kojom pojedinac dijeli (zamišljeno) zajedničko podrijetlo, jezik, običaje, kulturu, ideju zajedničke sudbine i sl., a ne o doživljaju vezanosti za državu-naciju kao političku tvorevinu. Rasprava o tome je li ovdje riječ o etničkom ili nacionalnom identitetu prelazi okvire ovoga rada, a zbog pojmovne jasnoće ističemo naziv instrumenta koji je upotrijebljen te, $u$ skladu s time, i naziv konstrukta. Kada, međutim, govorimo o međugrupnim odnosima većine i manjine u zajednici, rabimo pojam međuetnički, a ne međunacionalni odnosi.

Ajduković, D. i Čorkalo Biruški, D. (2008). Caught between the ethnic sides: Inter-ethnic relations of children and parents in the post-war community. International Journal of Behavioral Development, 32(4), 337347. doi:10.1177/0165025408090975

Allport, G. (1954). The nature of prejudice. (Unabridged) Reading, MA: Perseus Books.

Babić, D. (2008). Suživot Hrvata i Srba u Slavoniji. (Re)konstrukcija multietničkih lokalnih zajednica nakon ratnih sukoba. Zagreb: Golden Marketing-Tehnička knjiga.

Babić, D. (2010). Etnonacionalizam $i$ rat u Hrvatskoj. Teorijski aspekti $i$ istraživanje međunacionalnih odnosa u lokalnim zajednicama. Zagreb: Plejada.

Barrett, M. (2007). Children's knowledge, beliefs and feelings about nations and national groups. Hove and New York: Psychology Press.

Binder, J., Brown, R., Zagefka, H., Funke, F., Kessler, T., Mummendey, A., Maquil, A., Demoulin, S. i Leyensm J.-P. (2009). Does contact reduce prejudice or does prejudice reduce contact? A longitudinal test of the contact hypothesis among majority and minority groups in three European countries. Journal of Personality and Social Psycholo$g y, 96(4), 843-856$. doi:10.1037/a0013470

Brewer, M. B. (2001). Ingroup identification and intergroup conflict: When does ingroup love become outgroup hate? U R. D. Ashmore, L. Jussin i D. Wilder (Ur.), Social identity, intergroup conflict, and conflict reduction (str. 17-41). Oxford: Oxford University Press.

Brown, R., Eller, A., Leeds, S. i Stace, K. (2007). Intergroup contact and intergroup attitudes: A longitudinal study. European Journal of Social Psychology, 37(4), 692-703. doi:10.1002/ejsp.384

Čorkalo, D. i Kamenov, Ž. (2003). National identity and social distance: Does in-group loyalty lead to outgroup hostility? Review of Psychology, 10(2), 85-94.

Čorkalo Biruški, D. i Ajduković, D. (2007). Separate schools - divided community: The role of school in post-war social reconstruction. Review of Psychology, 14(2), 93-108.

Čorkalo Biruški, D. i Ajduković, D. (2008a). Stavovi učenika, roditelja i nastavnika prema školovanju: Što se promijenilo tijekom šest godina u Vukovaru? Migracijske i etničke teme, 24(3), 189-216. 
DRUŠ. ISTRAŽ. ZAGREB GOD. 21 (2012), BR. 4 (118)

STR. $901-921$

ČORKALO BIRUŠKI, D., AJDUKOVIĆ, D.: ŠTO ODREĐUJE...
Čorkalo Biruški, D. i Ajduković, D. (2008b). Promjene međuetničke diskriminacije $u$ djece i međuetnički stavovi i ponašanja njihovih roditelja. Ljetopis socijalnog rada, 15(3), 377-400.

Čorkalo Biruški, D. i Ajduković, D. (2009). Školovanje djece u Vukovaru: Je li se što promijenilo tijekom šest godina? Sažetak i preporuke sa stručnog skupa održanog u Vukovaru, 29. i 30. svibnja 2009. Neobjavljeno.

Čorkalo Biruški, D. i Ajduković, D. (2012a). Parallel world of divided community: Time does not make much difference. U O. Simić, Z. Volčić i C. R. Philpot (Ur.), Peace psychology in the Balkans: Dealing with a violent past while building peace (str. 177-198). New York: Springer.

Čorkalo Biruški, D. i Ajduković, D. (2012b). Škola kao prostor socijalne integracije djece i mladih u Vukovaru. Zagreb: Zaklada Friedrich Ebert.

Doosje, B., Ellemers, N. i Spears, R. (1999). Commitment and intergroup behavior. U N. Ellemers, R. Spears i B. Doosje (Ur.), Social identity: Context, commitment, content (str. 84-106). Oxford: Blackwell.

Feddes, A. R., Noack, P. i Rutland, A. (2009). Direct and extended friendship effects on minority and majority children's interethnic attitudes: A longitudinal study. Child Development, 80(2), 377-390. doi:10.1111/j.1467-8624.2009.01266.x

Gaertner, S. L. i Dovidio, J. F. (2009). A common ingroup identity: A categorization-based approach for reducing integroup bias. U T. Nelson (Ur.), Handbook of prejudice, stereotyping and discrimination (str. 489-505). Philadelphia: Taylor \& Francis.

Gallagher, T. (2004). Education in divided society. Houndmills, Basingstoke: Palgrave Macmillan.

Hewstone, M., Rubin, M. i Willis, H. (2002). Intergroup bias. Annual Review of Psychology, 53(1), 575-604. doi:10.1146/annurev.psych.53. 100901.135109

Jackson, J. W. (2002). The relationship between group identity and intergroup prejudice is moderated by sociostructural variation. Journal of Applied Social Psychology, 32(5), 908-933.

Mesic, M. i Baranovic, B. (2005). National minority education in Croatia. U N. Genov (Ur.), Ethnicity and educational policies in South Eastern Europe (str. 64-68). Muenster: Lit Verlag.

Mullen, B., Brown, R. i Smith, C. (1992). In-group bias as a function of salience, relevance and status: An integration. European Journal of Social Psychology, 22(2), 103-122. doi:10.1002/ejsp.2420220202

Oppenheimer, L. i Barret, M. (Ur.) (2011). National identity and ingroup/out-group attitudes in children: The role of sociohistorical settings. Special Issue of European Journal of Developmental Psychology, 1. doi:10.1080/17405629.2010.533948

Pettigrew, T. F. i Tropp, L. R. (2011). When groups meet: The dynamics of intergroup contact. New York: Psychology Press.

Raabe, T. i Beelmann, A. (2011). Development of ethnic, racial, and national prejudice in childhood and adolescence: A multinational meta-analysis of age differences. Child Development, 82(6), 1715-1737. doi:10.1111/j.1467-8624.2011.01668.x 
DRUŠ. ISTRAŽ. ZAGREB GOD. 21 (2012), BR. $4(118)$

STR. $901-921$

ČORKALO BIIRUŠKI, D., AJDUKOVIĆ, D.: ŠTO ODREĐUJE.
Schofield, J. W. i Eurich-Fulcer, R. (2003). When and how school desegregation improves intergroup relations. U R. Brown i S. Gaertner, S. (Ur.), Blackwell Handbook of social psychology: Intergroup processes (str. 475-494). Malden, MA: Blackwell Publishers.

Shamir, M. i Sagiv-Schifter, T. (2006). Conflict, identity and tolerance: Israel in the Al-Aqsa intifada. Political Psychology, 27(4), 569-595. doi:10. 1111/j.1467-9221.2006.00523.x

Szalai, J. (2011). Ethnic differences in education and diverging prospects for urban youth in an enlarged Europe. Summary findings. Budapest: Center for Policy Studies, Central European University.

Tajfel, H. (1978). The social psychology of minorities. London: Minority Rights Group.

Tajfel, H. i Turner, J. (1986). The social identity theory of intergroup behavior. U S. Worchel i W. G. Austin (Ur.), Psychology of intergroup relations (str. 7-24). Chicago: Nelson-Hall Publishers.

Tropp, L. R. i Pettigrew, T. F. (2005). Relationships between intergroup contact and prejudice among minority and majority status groups. Psychological Science, 16(12), 951-957. doi:10.1111/j.1467-9280.2005.01643.x

Tropp, L. R. i Prenovost, M. A. (2008). The role of intergroup contact in predicting children's interethnic attitudes. Evidence from metaanalytic and field studies. U S. R. Levy i M. Killen (Ur.), Intergroup attitudes and relations in childhood through adulthood (str. 236-248). Oxford: Oxford University Press.

Ustavni zakon o pravima nacionalnih manjina. Narodne novine, br. $152 / 2002$.

Verkuyten, M. (2005a). The social psychology of ethnic identity. Hove: Psychology Press.

Verkuyten, M. (2005b). Ethnic group identification and group evaluation among minority and majority groups: Testing the multiculturalism hypothesis. Journal of Personality and Social Psychology, 88(1), 121-138. doi:10.1037/0022-3514.88.1.121

Verkuyten, M. (2008). Multiculturalism and group evaluations among minority and majority groups. U S. Levy i M. Killen (Ur.), Intergroup attitudes and relations in childhood through adulthood (str. 157-172). Oxford: Oxford University Press.

Verkuyten, M. i Reijerse, A. (2008). Intergroup structure and identity management among ethnic minority and majority groups: The interactive effects of perceived stability, legitimacy and permeability. European Journal of Social Psychology, 38(1), 106-127. doi:10.1002/ejsp.395

Vermeij, L., van Duijn, M. A. J. i Baerveldt, C. (2009). Ethnic segregation in context: Social discrimination among native Dutch pupils and their ethnic minority classmates. Social Networks, 31(4), 230-239. doi:10.1016/j.socnet.2009.06.002

Vervoort, M. H. M., Scholte, R. H. J. i Scheepers, P. L. H. (2011). Ethnic composition of school classes, majority-minority friendships, and adolescents' intergroup attitudes in the Netherlads. Journal of Adolescence, 34(2), 257-267. doi:10.1016/j.adolescence.2010.05.005

Wagner, U., Christ, O., Wolf, H., van Dick, R., Stellmacher, J., Schlueter, E. i Zick, A. (2008). Social and political context effects on inter- 
DRUŠ. ISTRAŽ. ZAGREB GOD. 21 (2012),

BR. $4(118)$

STR. $901-921$

ČORKALO BIIRUŠKI, D., AJDUKOVIĆ, D.: ŠTO ODREĐUJE... group contact and intergroup attitudes. U U. Wagner, L. R. Tropp, G. Finchilescu i C. Tredoux (Ur.), Improving intergroup relations: Building on the legacy of Thomas F. Pettigrew (str. 195-209). Malden, MA: Blackwell.

Wright, S. C. i Tropp, L. R. (2005). Language and intergroup contact: Investigating the impact of bilingual instruction on children's intergroup attitudes. Group Processes E Intergroup Relations, 8(3), 309-328. doi:10.1177/1368430205053945

Zakon o odgoju i obrazovanju na jeziku i pismu nacionalnih manjina. Narodne novine, 51/2000.

\section{What Determines Adolescents' Interethnic Attitudes In a Divided Community?}

Dinka ČORKALO BIRUŠKI, Dean AJDUKOVIĆ Faculty of Humanities and Social Sciences, Zagreb

School is an important socialization agent as it provides knowledge, relates social norms and values, maintains ethnic identity, and promotes desirable behaviors. Its identity formation function is particularly evident in the schooling of minorities. The present study focuses on attitudes towards school and social integration of children in Vukovar who attend separate classes with teaching either in Croatian or Serbian language. This system was established by the Erdut Agreement in 1995, and continues today. The study explored if attitudes towards interethnic integration inside and outside of the school can be predicted by sociodemographic and identity variables, attitudes towards value of education, interethnic attitudes and behaviors. A series of hierarchical regression analyses were performed on data from Croat and Serb children aged 12 to 16 years, gathered in 2001 ( $N=718)$ and $2007(N=703)$. The results show that identity, interethnic attitudes and behaviors are very good predictors of attitudes in both areas of interethnic integration. The prediction was better for majority children, and somewhat better regarding school integration. Interethnic attitudes were increasingly stronger predictors of integration attitudes over time, suggesting in-group homogenization of children. Implications are discussed in the context of majority-minority relations in multiethnic communities and the role of school in integration processes.

Keywords: interethnic attitudes and behaviors, minority education, ethnic identity, minority and majority relations 